$\begin{array}{ll} & \text { Etnográfica } \\ \text { etnográfica } & \text { Revista do Centro em Rede de Investigação em }\end{array}$

Antropologia

vol. 21 (1) | 2017

Vol. $21(1)$

\title{
Beyond Martim Moniz: Portuguese Hindu Gujarati merchants in Lisbon
}

Para lá do Martim Moniz: comerciantes portugueses hindus-gujaratis em Lisboa

\section{Rita Cachado}

\section{OpenEdition}

\section{Journals}

Electronic version

URL: https://journals.openedition.org/etnografica/4871

DOI: 10.4000/etnografica.4871

ISSN: 2182-2891

\section{Publisher}

Centro em Rede de Investigação em Antropologia

\section{Printed version}

Date of publication: 1 February 2017

Number of pages: $203-220$

ISSN: 0873-6561

\section{Electronic reference}

Rita Cachado, "Beyond Martim Moniz: Portuguese Hindu Gujarati merchants in Lisbon", Etnográfica [Online], vol. 21 (1) | 2017, Online since 11 March 2017, connection on 09 February 2022. URL: http:// journals.openedition.org/etnografica/4871 ; DOI: https://doi.org/10.4000/etnografica.4871

\section{(c) (i) (8)}

Etnográfica is licensed under a Creative Commons Attribution-NonCommercial 4.0 International License. 


\section{Beyond Martim Moniz: Portuguese Hindu Gujarati merchants in Lisbon}

\section{Rita Cachado}

Portuguese Hindus living in Greater Lisbon are globally considered as virtuous merchants and they hardly escape this stereotype, which is also appended to other South Asian populations living in Lisbon, regardless of its accuracy. Moreover, common sense features the location of these merchants' shops circumscribed to Martim Moniz (near the downtown area). Nevertheless, Portuguese Hindu merchants, as well as other South Asian shopkeepers in Lisbon, have shops spread all over the city. In this article, I give a portrait of Portuguese Hindu merchants in Lisbon in a threefold way. One that unravels the different locations of their stores; another that approaches the diversity of their markets; and finally one that will draw on their view about the Portuguese economic crisis and its implications for their businesses. Until recently, Portuguese Hindus' professional trajectories were associated with an upward social mobility. Presently, what are their perspectives made of? How does the economic crisis affect their businesses? Do they prefer to migrate again as their families did two or three times before?

KEYWORDS: Ethnic economy, Portuguese Hindu merchants, transnationality, mixed embeddedness.

Para lá do Martim Moniz: comerciantes portugueses hindus-gujaratis em Lisboa - Os hindus portugueses que vivem na Grande Lisboa são geralmente vistos como comerciantes esmerados e raramente escapam a este estereótipo, que também recai sobre outras populações sul-asiáticas residentes em Lisboa. Além disso, o senso comum sobre estas populações diz que o seu comércio está centrado no Martim Moniz. No entanto, as lojas de comerciantes hindus portugueses, assim como as de outros comerciantes sul-asiáticos em Lisboa, estão por toda a cidade. Neste artigo retrato os comerciantes hindus em Lisboa de três maneiras: uma que dá conta das suas diferentes localizações; outra que aborda a diversidade da oferta; e, finalmente, uma que dá conta da sua visão sobre a crise económica em Portugal e as implicações desta na sua vida e negócios. Até recentemente, as trajetórias profissionais dos hindus portugueses estavam associadas a uma mobilidade social ascendente. Atualmente, quais são as suas perspetivas? Como a crise económica afeta os seus negócios? Preferem emigrar de novo como as suas famílias fizeram já duas ou três vezes?

PALAVRAS-CHAVE: economia étnica, comerciantes portugueses hindus, localidade, transnacionalidade.

CACHADO, Rita (rita.cachado@iscte.pt) - Instituto Universitário de Lisboa (ISCTE-IUL), Centro de Investigação e Estudos de Sociologia (CIES-IUL), Lisboa, Portugal. 


\section{INTRODUCTION}

When one walks through downtown Lisbon one easily comes across a number of souvenir shops with South Asian employees. ${ }^{1}$ The South Asian presence in Portugal is not new; populations from the Indian sub-continent, though working in diverse businesses, have been seen in the commerce area for the last 30 years. Until recently their visibility in Lisbon was centred on the Martim Moniz area, which has been focus of debate by Jorge Malheiros (1996) and José Mapril (2013). Mapril explains the insertion of South Asians in Martim Moniz as related to three fundamental factors: the diversity of urban policies implemented there; Lisbon's economic transformations; and migrant flows since the 1970s (Mapril 2013: 511). Nowadays we see "Asian" shops throughout the downtown area, many along its main arteries. Mikel Aramburu Otazu (2002) noted a similar process in Barcelona, where some groups of recent immigrants exploit a thriving tourism market in the centre of the Catalonian capital. Formerly, this type of settlement in the city configured what has been known as agglomeration economies (Waldinger, Mc. Evoy and Aldrich 1990, apud Kaplan 1998). This blooming market might be addressed as a branch of what Sharon Zukin (2009) called the urban homogenization process.

Less visible than the ones located downtown are the old "Asian" shops spread all over the Portuguese capital and suburban areas. Lisbon residents and workers know them. There's the Indian stationery, the Indian shoemaker, the Indian goldsmith, the Indian haberdashery, the Indian kiosk, the Indian hairdresser. But although the literature about Portuguese South Asians is becoming more profuse, few works address the "Indian" businesses in Lisbon.

Until recently, literature on ethnic minorities lacked work about the economic contexts and at the same time social scientists approached these groups without debate on why they were named ethnic in the first place (Rath and Kloosterman 2000). Nowadays, while studying ethnic entrepreneurs and other available categories, the researcher may feel a lack of ethnographies that could explain the practices of these groups. Most papers are dedicated to the discussion of terminology and they do propose insights considering economic conditions: whether the groups correspond to active entrepreneurship strategies based on different types of ethnic networks (e.g. Min and Bozorgmehr 2000); whether groups concentrate in an urban area and therefore in what ways they can be inscribed in the enclave concept (Ram et al. 2002); whether groups with old family networks are better equipped to face economic difficulties (e.g. Rath and Kloosterman 2000). These are important accounts that help to avoid a priori assumptions when writing about ethnic businesses. However, 
there is practically no work about business diversity among these same groups, and about their urban space embeddedness.

Moreover, the urban insight is a useful tool to avoid essentialization while approaching what has been abusively accounted for as "ethnic economies," as Rath and Kloosterman (2000: 12) warn. Analysing the urban context is looking at specific locations of insertion, and at the relationship between these businesses' locations and their surroundings. An outlook of the urban dispersion of Portuguese Hindu Gujarati entrepreneurs on the one hand, and their different insertions, on the other, will contribute, as I hope, to transcend the danger of essentialization.

South Asian communities throughout the world have been studied under a great diversity of perspectives, and one of them is the ethnic entrepreneurship approach. Academic literature dedicated to this topic is due to two major factors. The first relates to a very visible diaspora, to the presence of "little Indias" in global cities; the second is related to the historic bias regarding South Asian propensity to engage in business activities.

Considering the Portuguese dimension, there is an interesting literature about South Asians entrepreneurship. Authors do not only make historical insights, but also go deep into debates on postcolonial relationships (Bastos 2005; Trovão 2012; Mapril 2013; Dias 2016), and on socio-political chances for these groups. Ávila and Alves (1993) wrote one of the first papers about Indian businesses in Portugal. They distinguish among religious categories and note the economic advantages of the Ismaili group concerning social embeddedness (Ávila and Alves 1993: 131). These authors also point out the activation of cultural networks developed in Mozambique, the country of origin they migrated from in the early 1980s. This last point has been recently discussed by other authors who pursue research on the economic aspects of the South Asian communities in Portugal. Nuno Dias (2016) goes deeply into the business bias pending over "Indians" in the diaspora. He makes an account of its origins and relates it to the growing Indian populations in East Africa in the nineteenth century (Dias 2016: 50). Nevertheless, the Indian alleged proclivity to businesses was (and still is) characterized by ambiguity - they were seen as reliable partners for their resilient qualities as businessmen, but at the same time they were under surveillance for their fast economic ascendance in host countries (Dias 2016: 51).

In the international literature there is a noteworthy reproduction of Cohen's idea of trade diasporas (Cohen 1997) and sometimes the suggestion of replacing diaspora for emporium (Leontis 1997) to nominate specific trade diasporas as is the "Indian" case (Dwyer 2010: 87). Moreover, there is also the notion of "transnational commodity cultures" (Jackson, Crang and Dwyer 2004), or the remarkable "suitcase economies" phrasing from Rabine (2002). Although these terms and formulations can be useful to approach the limits and potentialities 
of diaspora and transnationality concepts when considering Hindu Gujarati migrants (among other groups with similar types of settlement in host societies), they actually highlight the business bias towards South Asians.

This article does not intend to offer new theoretical perspectives about ethnic entrepreneurship. My goal is primarily ethnographic, and it aims firstly to contribute to make further comparisons with other similar groups in globalized cities, whether they are called ethnic enclaves or ethnic entrepreneurs with more or less economic success. Secondly, with this article I intend to bring forward the fact that South Asian merchants ${ }^{2}$ in Lisbon are dispersed in the city, though mainly in delimited areas, which does not correspond to what has been designated as an ethnic enclave. However, as we will see, they match some situations that several authors with work in other cities have already recounted. So, in order to strengthen these arguments, the stories of four shopkeepers with concurrent yet diverse narratives will facilitate a debate about the ambiguity of the theoretical drawers in which they have been classified.

Besides this introduction, the article presents a historical outline, and then an overview on South Asian businessmen's current situation and their locations in Lisbon. After, the article will introduce more precisely a group of merchants, their shops and their discourses about the recent economic crisis.

\section{PORTUGUESE HINDU GUJARATIS IN LISBON}

The history of the South Asian presence in Lisbon should be taken into account in order to better identify the group of people about whom I develop my approach. Many authors have done this before, so I will only point to the literature concerning the population I have been working with and summarize their history.

Hindu Gujaratis in Portugal migrated from India to Mozambique mainly over the last hundred years. ${ }^{3}$ This movement follows two historical trends in the Indian Ocean: general migration from the Indian subcontinent to East Africa corresponding to work demands, and specific migration from and to both the British and the Portuguese colonial domains. Though thousands of Hindus in Mozambique came from Diu and Goa (former Portuguese colonies in India), other thousands came from several Gujarati cities, which were under British rule, either to Mozambique or to other East African countries.

2 It is important to note that the word "merchant" used here is a general job specification and not only related with merchants' castes.

3 In this article I concentrate on Hindu Gujaratis. Nevertheless, considering religion, in Portugal we find Goan Catholics, Gujarati Muslims and Ismailis, and Muslims and Hindus from other parts of South Asia. Considering nationality, South Asian families have their origin in India, Pakistan, Bangladesh, Nepal, Sri Lanka. Most Gujaratis came in the early 1980s from East African countries, mostly from Mozambique, but also from Tanzania and Kenia. From other parts of South Asia, the migration is more diluted in the middle 1990s, the early 2000s and the early 2010 s. 
After Mozambique's independence in 1975, Hindu Gujaratis started to migrate again, this time towards Portugal. The great majority came in the early 1980s in the context of the civil war aggravation (Bastos and Bastos 2001), but this migration started as early as the date of independence, and merchants opened their shops in Lisbon since the late 1970s. One of the first authors to make a portrait of the first great migration in the 1980s from Mozambique to Portugal, describing its insertion in the Lisbon Metropolitan Area, was Jorge Malheiros (1996), but before him, Susana Bastos started the literature on Portuguese Gujaratis with a work on housing problems and Hindu households (Bastos 1990). During the $21^{\text {st }}$ century, Hindu Gujaratis in Portugal were approached under a variety of themes, from identity (Bastos and Bastos 2001), to education (Seabra 2010) and gender (Lourenço 2010), housing (Cachado 2013) and, central to this paper, entrepreneurship (Marques, Oliveira and Dias 2002; Machado and Abranches 2005). All of them contributed to knowing these communities better, and to generate a specific Portuguese socio-anthropological literature on the subject. ${ }^{4}$

Although many families migrated once more during the 1990s and early 2000s, this time mainly to the United Kingdom, others preferred to stay in Portugal. It is important to note that professionally speaking, Hindus are not only merchants and shopkeepers, but also, among many other occupations in the services, domestic servants, masons or workers in other construction jobs, though these last have been in decline throughout the years of settlement (Machado and Abranches 2005: 82).

Up to this moment I have not mentioned any population numbers. This is due not only to the fact that exact numbers are not available through official censuses, but also because part of this transnational population, namely retired people, are actually living both in Portugal and in the United Kingdom or India, which leads to an impossible agreement concerning the total number of Portuguese Hindu Gujaratis. That is to say that their transnationality, regarding the fact that they sustain "multi-stranded social relations that link together their societies of origin and settlement" (Basch, Schiller and Blanc 1994: 7), is rather objective, since they actually live in two or more countries, and for that reason there are no accurate numbers on their presence in Portugal. Nevertheless, some authors, while acknowledging these data issues, point to around 33,000 Hindus in Portugal (Lourenço e Cachado 2012; Dias 2016), which is an indicative number whose weaknesses should always be underlined.

In the late 1990s, it was agreed in the literature that most South Asians living in Portugal were employed in commerce, hotel and tourism businesses, and in construction (Baganha, Ferrão and Malheiros 1999). While studying

4 Most of these papers were published in Portuguese and unfortunately the Anglo-Saxon literature on South Asians rarely acknowledges this plural and interesting context. 
immigrant entrepreneurs in Portugal, Marques, Oliveira and Dias (2002: 138-139) state that the length of residence in Portugal is crucial to understand immigrant insertion in the labour market. Following their thought, it is important to make clear that in this article I am addressing a group that has been living in Portugal for a long time, about 30 years. Similarly, the reflection of Machado and Abranches (2005) is significant for the scope of this article. They refer that besides their own work, there is almost no published research about immigrant professional trajectories in Portugal, which is due to the fact that until recently there was no temporal depth (Machado and Abranches 2005: 70). Portuguese literature on immigration concentrates on integration issues, but beyond recent migration groups there are populations that have been living in Portugal for more than 20 years, which provides a great opportunity to study professional trajectories. Machado and Abranches (2005) address Cape Verdeans and Hindus, concluding for the latter with a query for future research: will the logic of expansion of independent work maintain its ability to function as it did up to now? Therefore, in my interview guide the need to answer that question was implicit. Their methodology is also useful for my approach, since they concentrated on four periods to address life courses: the two years before migrating, one year after arrival, the midterm year, and the present moment. I generally followed that line in my own research, though with no statistical scope.

The merchants among whom I conducted fieldwork in 2013-2014 are Hindu Gujaratis who came to Portugal in the late 70 s and early 80 s. I selected four stories among a group of 13 interviews conducted in different shops in central Lisbon. Acknowledging that most work about South Asian merchants has been carried out around the Martim Moniz area (Malheiros 2008; Menezes 2009; Mapril 2010), I decided to move beyond this area, although only in a radius of two kilometres. Another reason for doing so was that nowadays Lisboners know that South Asian commerce is not only concentrated in Martim Moniz, it is also south and northwards. Martim Moniz is known as the first and principal area where South Asian merchants installed their shops, but more careful observation, as Malheiros showed before (Malheiros 1996), reveals that actually even very old "Indian" shops are outside Martim Moniz, and this is what I will corroborate below, enlarging the field. But we also should note that shops held by Hindu Gujaratis in Lisbon can be found in every neighbourhood of Lisbon.

\section{HINDU GUJARATI SHOPKEEPERS IN LISBON: FOUR PERSPECTIVES}

This section will provide the reader with four stories of Hindu Gujaratis shopkeepers in Lisbon. The intention here is to briefly recount their professional trajectories in Portugal; to present their thoughts about the economic crisis; 
and to illustrate how it affects their life-course decisions. But before getting to this, I will give a brief overview of the current situation of South Asian merchants in Lisbon to situate my informants.

Lisbon citizens (residents and/or workers) easily notice the recent growth of souvenir shops owned by South Asian shopkeepers. There are both Punjabi and Bengali shopkeepers, although the former have recently been less present than the latter. ${ }^{5}$ Dozens of souvenir shops, which sometimes are also grocery stores, are spread throughout downtown Lisbon. There are also a growing number of grocery stores run by South Asians in every Lisbon neighbourhood. These minimarkets are replacing former minimarkets and grocery stores whose role is to provide the elderly with daily goods close to home and therefore prevent their need to go to big supermarkets. ${ }^{6}$ This situation matches the case observed by Cébrian de Miguel and Bodega Fernández (2002: 577) in Lavapiés, Madrid, where South Asian migrants have replaced old Spanish stores maintaining the pre-existent businesses.

To make an overview of this recent situation, I took Rua da Prata as emblematic of a typical shopping street in central Lisbon at the present time. ${ }^{7}$ Rua da Prata is a good example as, apart from the presence of these shops, it has a lot of Portuguese traditional clothes and accessories stores that did not close after the arrival of major international brands, nor following the economic crisis. In Portugal, as similarly in Ireland and in Greece to a certain extent, the economic crisis grew with an austerity policy instituted by the XIX Government (201 1-2015). ${ }^{8}$ The street also lodges shops specialized in selling Portuguese old brands and Portuguese old representations. ${ }^{9}$ Considering non-Portuguese

5 The reference here is to the sub-continent region, though most Bengalis in Portugal are Bangladeshis. Sikhs, which form the overall Punjabi population in Portugal, were approached by Bastos and Correia (2006) and by Rajput (2012). The latter remarks that many Punjabis migrated recently to the United Kingdom. No conclusive data is available concerning total populations. Bangladeshi Muslims were profusely addressed by Mapril (e.g. 2009, 2012), though many Bangladeshis arrived in Lisbon after his main work about this population.

6 Furthermore, these stores offer the service of home delivery, hypothetically competing with large supermarkets that do the same for online orders.

7 Actually, I could also have chosen other streets downtown, such as Rua do Arsenal or Rua Augusta, but Rua da Prata seems to provide a wider range of situations than the other two. Nevertheless, each of these examples should be further ethnographed. Note that this situation was recorded in early 2014. See Brody (2005), and Cordeiro and Vidal (2008) for works about "the street" with a socio-anthropological focus.

8 Few academic accounts have been published so far about this traumatic situation for the Portuguese economy as a whole and for Portuguese families in general. Migration was particularly affected by the growth of emigration rates and decrease of immigration.

9 Such as Portuguese old tiles printed on t-shirts and fridge magnets, among other items more related to specific brands. The concept of selling old Portuguese brands was mainly developed by Catarina Portas and her Vida Portuguesa stores in the early 2000s, which was rapidly spread and copied by tourism promoters, conforming to a vintage style trend. 
stores, there are 20 shops run by South Asians in Rua da Prata, and three Chinese clothes and accessories stores. South Asian stores include three shops selling clothes, accessories and souvenirs, run by Indians who came in the early 1990s to Lisbon, and 17 souvenir shops that my fieldwork didn't embrace, whose shopkeepers are chiefly Bangladeshis.

Two hundred metres north we find Praça Martim Moniz. This square has been subject to a series of urban pro-multicultural projects (see Menezes 2009; Mendes 2012). Situated between two shopping centres whose shops are mainly managed by so-called ethnic minorities, namely South Asian, Chinese and from several African origins, Martim Moniz is also the joining point of a number of streets that in the early 80s were filled with Indian stores: little streets such as Rua de Benformoso and Rua dos Cavaleiros (well known in the literature) with gift stores; and Rua da Palma along with the following Avenida Almirante Reis with Ismaili furniture stores. In recent years, after 2008, the latter were affected by the economic crisis; Avenida Almirante Reis has a large number of old furniture stores that have been closed or replaced by Chinese stores or, though open, have signboards indicating that they are for sale or lease transfer. During the austerity period but chiefly in its wake, an enormous housing trend has been notable: old buildings become hostels to fulfil tourism demands (see Pavel 2015).

Avenida Almirante Reis, 2 kilometres long, ${ }^{10}$ is visibly dotted with South Asian and Chinese stores, and is frequented and dwelt in by people of many nationalities. The historic Mouraria neighbourhood, which lies northeast between the Martim Moniz and the Intendente area up to the Graça neighbourhood, ${ }^{11}$ is inhabited by both elderly Portuguese dwellers and immigrants from dozens of nationalities that, since the late 1970s, have been arriving in Lisbon. Both old and recent immigrants from either different African origins or diverse South Asian countries and China are noticed by visitors. The short narratives that will be presented below are from shops located around the middle of Avenida Almirante Reis, comprising the Anjos and Arroios areas. Anjos and Arroios are subway stations and epitomise their enlarged areas. As Simone Frangella puts it, Arroios "seems to work mainly as a point of concentration and information for migrants, and moreover it is a place of both residence and work" (free translation from Frangella 2013: 464).

\section{Mr. Inesh}

This first case portrays a Portuguese Hindu Gujarati shoemaker whose shop is in Rua de Angola. Mr. Inesh ${ }^{12}$ has a life course with little changes, despite

10 And if we add Rua da Palma, the total length adds up to 2,5 kilometres.

11 Mouraria's limits, as is usual for historical neighbourhoods in Lisbon, are difficult to specify (Menezes 2004).

12 Though the shopkeepers I interviewed were informed about my work and agreed to make their statements public, I prefer to maintain their anonymity and replace their real names with pseudonyms. 
migration. He was born in Maputo. Aged seven, he learnt the shoemaker trade with his father and worked from then on as a shoemaker in Maputo. He first visited Portugal in 1976 for 15 days to "have a look" and he liked Lisbon right away. He only came back to stay in 1981 and has worked in his shop located in Rua de Angola, near Anjos, since then. He lives in Santo António dos Cavaleiros, a suburban area where Hindu Gujaratis tended to cluster in the early 1980s. He has two daughters and in his family he is the only one who remains in the shoemaker trade, since shoemaking is traditionally only for men. One of his daughters migrated to the United Kingdom, the other lives in Portugal. Mr. Inesh is presently 68 years old and continues to work as shoemaker.

The economic crisis has affected him to a certain extent: customers no longer buy handmade shoes from him, but many people are now requiring his repairing services. Nowadays people only ask for minimum services, instead of a full repair. He reckons that old shops from Portuguese Hindu Gujarati are spread throughout the city and not limited to the Martim Moniz area, and points to the fact that there is a great variety of shops. He exemplified with a jeweller nearby that installed his shop in 1977, and in Rua Morais Soares there are stationeries and haberdasheries that date back to the late 1970s, whose shopkeepers I visited and interviewed as well. ${ }^{13}$

\section{Mr. Rajesh}

The second example comes from Rua Morais Soares, where commerce is plural considering ethnic origins and diversified in terms of offer. Actually, this street has been a subject of debate by Simone Frangella (2013), who analyses the Brazilian migrant insertion. The author notes the lack of academic attention given to this area (Frangella 2013: 469) considering not only migration plurality but also urban change, to which I also subscribe. In Rua Morais Soares, we find old and recent stores, from old and recent shopkeepers and owners, and we find old Portuguese stores as well, that seem to resist despite the price pressure from neighbouring stores. The shopkeeper Mr. Rajesh of the store in question is a Portuguese Hindu Gujarati who arrived in Portugal in 1983 and, like Mr. Inesh, lives in Santo António dos Cavaleiros. He has owned the shop for the last 13 years and his wife works there with him. Before this business, shortly after arriving in Portugal, he had a grocery store in Odivelas (north Lisbon) which lasted three years but the business was not successful. Then he worked as an employee in a clothes store for six years in Rua dos Fanqueiros, in downtown Lisbon, which was a situation of economic dependence. After that he opened a store in Queluz (west Lisbon suburban area), which does not fit with the representative Hindu stores' areas in Lisbon, and finally got

13 Though interesting, I decided not to include these interviewees' among the selected stories because the ethnographic encounters were shorter than the average of the whole interviews. 
to Rua Morais Soares in 1999. Thus his trajectory matches the type of trajectories Machado and Abranches noticed in their work, where the authors highlighted the fact that there was a trend among Hindus to perform a trajectory of becoming independent workers after some years of settlement in Portugal (Machado and Abranches 2005: 72).

Mr. Rajesh notes that until the late 1990s the suppliers were mostly Portuguese from Northern Portugal, and from then on products began to be distributed chiefly by Chinese suppliers. He states that this situation marked the beginning of the economic crisis, not due to a supposed Chinese responsibility, but because of the open market as a whole.

Concerning the European economic crisis and the economic development in India, Mr. Rajesh states that the maintenance of social inequality weights more than the fact that India is growing economically. In other words, despite the economic development, inequalities among people unbalance the trend of supposed growth. Notwithstanding that "we're being robbed," as he said concerning higher taxes in Portugal, he doesn't foresee the possibility of going to India to make a living, or returning to Mozambique, which is also growing, though not in the same way as India. Even though "Portugal has no future," he states.

\section{Mr. Anand}

Mr. Anand has owned a shop in Rua Angelina Vidal (near Anjos, in the middle area of Avenida Almirante Reis) since 1987. The shop is a small drugstore, with a storefront of about $12 \mathrm{~m}^{2}$, but it seems to contain virtually everything one might need for toiletries and home cleaning. Whenever I visited the store I heard the customers call him by his nickname. Before owning this shop, Mr. Anand had worked as a warehouseman near Martim Moniz from the year of his arrival in Portugal, 1975, to 1985. His boss was his previous boss in Maputo, so he kept his previous employment relationships, which is a common situation among Hindu Gujaratis in Portugal, previously noted by other authors (Ávila and Alves 1993; Machado and Abranches 2005). Therefore, as in the case of Mr. Rajesh, Mr. Anand showed an ascending social mobility towards independent work. In his early years in Portugal, he lived in Quinta da Holandesa, an informal settlement, and was resettled in the mid-1990s to Bairro do Armador, which is dwelt in by hundreds of Hindu Gujarati families who were formerly also residents of Quinta da Holandesa. ${ }^{14}$ This is a common situation for many Hindu Gujaratis living in Greater Lisbon. When they

14 I prefer to use informal settlement but it is important to remark that shanty town would be the English closest term to the Portuguese bairros de barracas, which was the usual term used to describe Quinta da Holandesa and dozens of neighborhoods in the same housing situation (see Cachado 2012: 34-41). 
arrived in Portugal in the early 1980s, low income families felt the need to buy or rent a small space in so-called shanty towns where they built their own houses. Quinta da Holandesa and Quinta da Vitória were at that time the biggest Hindu Gujarati housing clusters. Most of the families were resettled under a huge social housing policy. ${ }^{15}$

Now, taking the economic crisis into account, Mr. Anand said that the economic crisis has been felt mostly in the last five years, despite the fact that he feels that in his particular case it does not affect the store that much, since he is able to maintain his fixed costumers. But around his shop, he can see great changes that may be a result of the austerity policies, namely the constant opening and closing of grocery and Internet-access stores managed by Pakistanis and Bangladeshis. Although the stores providing access to the Internet tend to close, grocery stores seem to replace old minimarkets throughout Lisbon. He notices the closing of old Portuguese small businesses and is grateful for the fact that his business is kept open. Part of Mr. Anand's family is employed in other stores, and the rest have other types of jobs and occupations.

These three stories portray different business situations with a similar perspective on the economic crisis: they do not feel the crisis as much as we could imagine, since in Portugal small businesses have been affected by the economic crisis and austerity policies to a great extent. Accordingly, they do not envision a backwards migration movement (either to Mozambique or India), nor forward (to the United Kingdom), for them and their nuclear families. Furthermore, these three stories also answer Machado and Abranches' doubt about whether Hindus could maintain the conditions for independent work. Despite the difficulties that arouse during the economic crisis, they do.

\section{Mr. Jaiantilal}

The last case presented here is slightly different from the others. Mr. Jaiantilal owns a stationery shop in Rua dos Correeiros, in downtown Lisbon. It is a big store, with virtually everything one can find in stationeries. He was born in Fudam, near Diu (former Portuguese colony in South Gujarat) and lived there until the age of four, when he migrated with his mother to Maputo (1964). Later, he migrated from Maputo to Lisbon in 1981. In Mozambique, Mr. Jaiantilal had worked in a clothes shop for a Muslim Indian boss, who also came to Portugal in the early 1980s and who owns a big stationery himself on Rua Morais Soares (see above), and for whom Mr. Jaiantilal worked for several years in Lisbon as well. In 1992 he bought his own stationery and has been

15 The Programa Especial de Realojamento (PER) was legislated in 1993 and resettled tens of thousands families in Lisbon and Porto. For more on Hindu families rehousing, see Cachado (2012). 
working there for the last 20 years. As in the above cases, Mr. Jaiantilal holds an independent job.

His family works in commerce as well, though not in stationeries, they work mostly in souvenir shops. Presently he lives in the same building where the stationery is located, but he used to live in Santo António dos Cavaleiros where hundreds of Hindu Gujarati families can be found. His parents live in Maputo and he currently considers opening a store there, though he has not yet decided in what business area. He has already placed an advertisement for renting his stationery and is waiting for a reply. His situation is thus different from the cases presented above. Mr. Jaiantilal is really worried about the Portuguese economic crisis, and he attentively follows the economic development in Mozambique. He notes that "Mozambique is not Angola" as he put it, pointing to the fact that Angola is much more prosperous than Mozambique, but he knows that in Mozambique the number of Chinese and Brazilian investors is growing, and that condition indicates significant economic development. Therefore, he is eager to take the chance and see what happens in the country where he lived before.

\section{Avoiding pigeonholes}

After all, what do these narratives have in common and what differentiates them? Do they reflect other authors' work on "ethnic economies"? As pointed before, the first three narratives have in common the fact that in those cases the need to migrate again is not felt. The last story differs from the others concerning attitudes towards the economic crisis, however all four situations of the "Indian" shops presented above mirror other situations conveyed in the international literature on ethnic economies. For instance, having the same boss they formerly had in Mozambique, as in the cases of Mr. Anand and of Mr. Jaiantilal, is related to the importance of ethnic strategies, as Waldinger, Mc. Evoy and Aldrich (1990) put it. Or, as Beltrán suggests, commercial traditions in the country of origin are central to understand embeddedness patterns (Beltrán 2000).

Another example is the fact that shopkeepers' relatives tend to work in commerce but not always, especially in the case of youngsters, that is, children get education and engage in other jobs (Baycan, Sahin and Nijkamp 2011: 971). That is the case of Mr. Inesh's daughters, and also of Mr. Anand's children, whose boy studied Management and intends to migrate, while the girl followed her father and is a shopkeeper, in a shop not far from her fathers'. It is important to highlight the fact that these trajectories are not only marked by independence in work but also by children's education and their different choices concerning work. Considering children's education, both parents and children portray the university as a good means to achieve economic independence in the future. Portuguese universities are presently good choices as they 
put it, but the United Kingdom keeps its symbolic power among Portuguese Hindu Gujarati families.

The most common situation found in the field has already been noted in this article: the desire of owning their own shop a few years after arrival in the host society, which is consistent with the findings of Machado and Abranches (2005), and has been accomplished by all the informants interviewed. Ultimately, that achievement is a "ticket to middle class," as David Kaplan stated (1998: 491). The gain of independence with the opening of a shop, and maintaining it over the years, is also related to the success of their location choice. The concentration of South Asian shops is not huge (as is in Martim Moniz and presently in part of downtown Lisbon); therefore, they achieved urban embeddedness and maintained it. On the one hand, they have contributed to diversify commerce in Lisbon; on the other hand, they have brought dynamism to a district (Anjos and Arroios) that has not been a target in Lisbon urban policies. However, the results of this study also show that despite the location of the shops, the interlocutors inhabit other areas in Greater Lisbon. Let's try to problematize this.

When speaking about the success of ethnic economies, there are authors who highlighted the importance of spatial clustering, whether of residence or business (see Kaplan 1998: 489). But literature about ethnic economies and clusters, more than drawing attention to residential clustering when addressing ethnic enclaves and ethnic economies, has emphasized shop clustering in a specific urban area (see also Kaplan 1998: 494), much more than housing clustering. Sometimes residential and business clustering match, as is the case of Hindus in Devon Avenue, Chicago, described by Ashutosh (2008). However, in Lisbon, I would call on residential clustering more than on shop clustering in the city. Hindu Gujarati merchants should not be labelled in the category of an ethnic enclave, because Hindu Gujarati stores and Hindu Gujarati residents don't concentrate only in specific areas. In simple terms, but underlining the fact that this is not a generalized situation, what I found was commercial spatial dispersion and housing clustering. But again, there are also situations of a high level of business spatial concentration and a low level of residential sprawl.

That said, the fact that Hindu commerce is spread throughout the city does not imply that we cannot use the word cluster to characterize them (Werbner 2001: 673). Werbner's argument rejects the notion of ethnic enclave economy as a territorially circumscribed place, but agrees with the importance of clustering for the success of ethnic enclave economies (2001: 677). Shop clustering is important among recent South Asian migrants in Lisbon, who have recently opened stores in downtown Lisbon, just as shop clustering in Martim Moniz was important for Hindu Gujarati who arrived in Lisbon in the early 1980s and is still important for South Asians nowadays (Mapril 2013). Now in what 
concerns residential clustering, it is significant that all the shopkeepers and shop owners who were interviewed (and I mean not only the four illustrative narratives but the whole 13), though living in different neighbourhoods, actually inhabit areas where other Hindus also live (Santo António dos Cavaleiros and Bairro do Armador). It is true that their shops are located in neighbourhoods where one can find other South Asian stores as well, but that kind of concentration is not as accentuated as is the fact that they live in the same neighbourhoods. And, again, diversity among South Asians (including a group of nationalities and religions) is stronger than what is "common" among them. In sum, what I wish to underline is that, as in many other cultural specific populations, norms are less important than differences among the same group.

\section{FINAL REMARKS}

While analysing Portuguese Gujarati entrepreneurs, it is important to maintain categories out of conceptual drawers. To begin with, the study of ethnic economies in urban contexts can contribute to a new perspective, aware and less shelved, of immigrants (see also Aramburu Otazu 2002; Rocha-Trindade 2007). In other words, there are new theoretical and methodological questions we can ask when we observe this kind of diversity in a certain field, such as: why are we calling these populations "migrants" if they have been settled for the last 30 years or more? The ethnographic account proves that the diversity of situations is in fact abundant. This article presented four heterogeneous cases. They (i) demonstrate an effective insertion (or embeddedness, following the ethnic economies jargon) in society; (ii) indicate the relevant role of ethnic networks; (iii) show diversity considering the ways families face the economic crisis: remigrating (Dias 2016), or waiting to see the development of affairs or youngsters' choice of jobs other than in commerce; and (iv) show the relative significance of clustering.

In this article, as in other works cited above, we can easily find examples that fit in culturalist, ecologic or integrationist model proposals. That is why it is paradoxically so difficult to decide if we should examine our population in the light of the concept of "ethnic economy," thus opting by a migration approach intersected by an approach of the type of economy chosen, or if we should rather speak about the significance of opportunity structure and about the host society conditions. These are different perspectives for the study of the same population which are suitable to various degrees. Therefore, perspectives that agree with the idea of mixed embeddedness (Kloosterman, van der Leun and Rath 1999) deserve, in my view, more attention, because it seems to merge the former varieties, despite the fact that the term itself is manifestly encrypted and sparingly useful to an anthropologic literature that is beyond ethnic economy studies. Mixed embeddedness actually combines the 
economic opportunities' structure with both the positive state policies regarding "ethnic economies" and the demand approach (Garcés 2011: 12).

There is no intention here to present an alternative to the plural and available concepts. I rather emphasize that the goal was to contribute to furthering our knowledge on the actual situation of South Asian commerce in Lisbon, specifically in old Hindu Gujarati shops that are not concentrated in one specific area. Indeed, the shops where I conducted fieldwork (including the ones that I did not bring to the paper as specific cases) are located in the larger area of Avenida Almirante Reis and adjacent neighbourhoods. Moreover, Hindu Gujarati shops can in fact be found all over the city. What I wish to underline is that the overused idea of ethnic enclave fades away in this article not only because these shops are spread in the city; it disappears also because while portraying a group of shopkeepers I do this looking at their history, and therefore naming them for their own distinctiveness, being Portuguese Hindu Gujarati entrepreneurs, and not for the reasons economic discourses usually name them.

They are actually beyond Martim Moniz, as the article title suggests, in twofold ways: geographically, and in their life trajectories, since some of them began their work life in Portugal actually in the Martim Moniz area, or began their lives in Portugal depending on what Martim Moniz represents - clustering and networking. As Ram et al. (2002) recall, for a long time studies on ethnic entrepreneurs ignored the urban context, focusing only on businesses and ethnicity (Ram et al. 2002: 24). The phrase "beyond Martim Moniz" is thus a way of illustrating not only the urban dispersal of "Indian" shops, but also of pointing to the multiple trajectories of a single population.

\section{REFERENCES}

ARAMBURU OTAZU, Mikel, 2002, "Los comércios de inmigrantes extrangeros en Barcelona y la recomposición del 'inmigrante' como categoría social”, Revista Electrónica de Geografía y Ciencias Sociales, VI (108), available at < http://www.ub.es/geocrit/sn/sn-108. htm > (last access in January 2017).

ASHUTOSH, Ishan (2008), "(Re-)creating the community: South Asian transnationalism on Chicago's Devon Avenue”, Urban Geography, 29 (3): 224-245.

ÁVILA, Patrícia, and Mariana ALVES, 1993, "Da Índia a Portugal: trajectórias sociais e estratégias colectivas dos comerciantes indianos”, Sociologia, Problemas e Práticas, 13: 115 $-133$.

BAGANHA, Maria Ioannis, João FERRÃO, and Jorge Macaísta MALHEIROS, 1999, "Os imigrantes e o mercado de trabalho: o caso português”, Análise Social, XXXIV (150): 147-173. 
BASCH, Linda, Nina Glick SCHILLER, and Cristina Szanton BLANC, 1994, Nations Unbound: Transnational Projects. Post-Colonial Predicaments and Deterritorialised Nation-States. Basel, Gordon and Breach Publishers, 1-19.

BASTOS, Susana Trovão Pereira, 1990, A Comunidade Hindu da Quinta da Holandesa: Um Estudo Antropológico sobre a Organização Sócio-Espacial da Casa. Lisbon, LNEC.

BASTOS, Susana Trovão Pereira, 2005, “'Our colonizers were better than yours': identity debates in Greater London”, Journal of Ethnic and Migration Studies, 31 (1): 79-98.

BASTOS, Susana Trovão Pereira, and José Gabriel Pereira BASTOS, 2001, De Moçambique a Portugal: Reinterpretações Identitárias do Hinduísmo em Viagem. Lisboa, Fundação Oriente.

BASTOS, Susana, and André CORREIA, 2006, "Quando ela estuda aqui ela não faz como eu quero: vulnerabilidades Sikh em Portugal", in José Gabriel Bastos and Susana Bastos (eds.), Filhos Diferentes de Deuses Diferentes: Manejos da Religião em Processos de Inserção Social Diferenciada. Uma Abordagem Estrutural Dinâmica, Lisboa, ACIME, 179-187.

BAYCAN, Tüzin, Mediha SAHIN, and Peter NIJKAMP, 2011, “The urban growth potential of second-generation migrant entrepreneurs: S sectorial study on Amsterdam”, International Business Review, 21: 971-986.

BELTRÁN, Joaquin, 2000, "Empresa familiar, trabajo, redes sociales y familia en el colectivo chino”, Ofrim/Suplementos, 6: 29-154.

BRODY, Jeanne (ed.), 2005, La Rue. Toulouse, Presses Universitaires du Mirail.

CACHADO, Rita d'Ávila, 2012, Uma Etnografia na Cidade Alargada: Hindus da Quinta da Vitória em Processo de Realojamento, Lisboa, Fundação Calouste Gulbenkian/Fundação para a Ciência e a Tecnologia.

CACHADO, Rita, 2013, “O Programa Especial de Realojamento: ambiente histórico, político e social”, Análise Social, 206 (XLVIII): 135-152.

CÉBRIAN DE MIGUEL, Juan, and Maria Isabel BODEGA FERNÁNDEZ, 2002, "El negocio étnico, nueva fórmula de comercio en el casco antiguo de Madrid: el caso de Lavapiés", Estudos Geográficos, LXIII (248/249): 559-580.

COHEN, Robin, 1997, Global Diasporas: An Introduction, London, UCL Press.

CORDeIRO, Graça, and Frederic VIDAL (eds.), 2008, A Rua: Espaço, Tempo, Sociabilidade. Lisbon, Livros Horizonte.

DIAS, Nuno, 2016, Remigração e Etnicidade: Trânsito Colonial entre a África de Leste e a Europa. Lisbon, Mundos Sociais.

DWYER, Claire, 2010, "Diasporas and economies", in Kim Knott and Seán McLoughlin (eds.), Diasporas: Concepts, Intersections, Identities. London and New York, Zed Books, 87-90.

FRANGELLA, Simone, 2013, “'Fomos conhecer um tal de Arroios': construção de um lugar na imigração brasileira em Lisboa”, in Nuno Domingos e Elsa Peralta (eds.), Cidade e Império: Dinâmicas Coloniais e Reconfigurações Pós-Coloniais, Lisbon, Edições 70, 463 -502 .

GARCÉS, Alejandro, 2011 , "Comercio inmigrante y economías étnicas: síntesis y críticas de los debates vigentes”, Polis, 29, available at < https://dialnet.unirioja.es/servlet/articulo? codigo $=4713042>$ (last access in January 2017).

JACKSON, Peter, Philip CRANG, and Claire DWYER (eds.), 2004, Transnational Spaces. London and New York, Routledge.

KAPLAN, David H., 1998, "The spatial structure of urban ethnic economies", Urban Geography, 19 (6): 489-501. 
KLOOSTERMAN, Robert, Joanne VAN DER LEUN, and Jan RATH, 1999, "Mixed embeddedness, migrant entrepreneurship and informal economic activities”, International Journal of Urban and Regional Research, 23 (2): 253-67.

LEONTIS, Artemis, 1997, "Mediterranean topographies before balkanization: on Greek Diaspora, emporium and revolution”, Diaspora, 6 (2): 179-194.

LOURENÇO, Inês, 2010, "Anthropological perspectives on female identity: the Hindu diaspora in Portugal”, International Journal of Interdisciplinary Social Sciences, 5: 143-150.

LOURENÇO, Inês, and Rita CACHADO, 2012, "Hindu transnational families: transformation and continuity in Diaspora families", Journal of Comparative Family Studies, 43 (1): 53-70.

MACHADO, Fernando Luís, and Maria ABRANCHES, 2005, "Caminhos limitados de integração social: trajectórias socioprofissionais de cabo-verdianos e hindus em Portugal”, Sociologia, Problemas e Práticas, 48: 69-91.

MALHEIROS, Jorge, 1996, Imigrantes na Região de Lisboa: Os Anos da Mudança: Imigração e Processo de Integração das Comunidades de Origem Indiana. Lisbon, Colibri.

MALHEIROS, Jorge, 2008, "Comunidades de origem indiana na Área Metropolitana de Lisboa: iniciativas empresariais e estratégias sociais criativas na cidade”, Migrações, 3: 139-164.

MAPRIL, José, 2009, "O lugar do sacrifício: qurbani e circuitos transnacionais entre bangladeshis em Lisboa”, Análise Social, XLIV (190): 7 1-103.

MAPRIL, José, 2010, "Banglapara: imigração, negócios e (in)formalidades em Lisboa”, Etnográfica, 14 (2): 243-263.

MAPRIL, José, 2012, Islão e Transnacionalismo: Uma Etnografia entre Portugal e o Bangladeche. Lisbon, Imprensa de Ciências Sociais.

MAPRIL, José, 2013, “Um lugar estrutural? Legados coloniais e migrações globais numa rua em Lisboa”, in Nuno Domingos and Elsa Peralta (eds.), Cidade e Império: Dinâmicas Coloniais e Reconfigurações Pós-Coloniais, Lisbon, Edições 70, 503-524.

MARQUES, Maria Margarida, Catarina Reis OLIVEIRA, and Nuno DIAS, 2002, "Empresários de origem imigrante em Portugal”, in António Oliveira das Neves (ed.), Imigração e Mercado de Trabalho, Lisbon, Ministério da Segurança Social e do Trabalho, Departamento de Estudos, Prospectiva e Planeamento, 131-144.

MENDES, Maria Manuela, 2012, "Bairro da Mouraria, território de diversidade: entre a tradição e o cosmopolitismo", Sociologia: Revista da Faculdade de Letras da Universidade do Porto, special issue "Imigração, diversidade e convivência cultural": 15-41.

MENEZES, Marluci, 2004, Mouraria, Retalhos de Um Imaginário: Significados Urbanos de Um Bairro de Lisboa. Oeiras, Celta Editora.

MENEZES, Marluci, 2009, "A praça do Martim Moniz: etnografando lógicas socioculturais de inscrição da praça no mapa social de Lisboa”, Horizontes Antropológicos, 32: 301-328.

MIN, Pyong Gap, and Mehdi BOZORGMEHR, 2000, "Immigrant entrepreneurship and business patterns: A comparison of Koreans and Iranians in Los Angeles", International Migration Review, 34 (3): 707-738.

PAVEL, Fabiana, 2015, Transformação Urbana de Uma Área Histórica: O Bairro Alto. Reabilitação, Identidade e Gentrificação. Lisbon, Faculdade de Arquitetura da Universidade de Lisboa, PhD thesis in Architecture.

RABINE, Leslie, 2002, The Global Circulation of African Fashion, Oxford, Berg. 
RAJPUT, Dimple, 2012, A Aprendizagem do Português enquanto Lingua de Acolhimento: A Comunidade Punjabi em Portugal. Lisbon, Faculdade de Letras da Universidade de Lisboa, M.A. thesis.

RAM, Monder, et al., 2002, "Ethnic minority enterprise in its urban context: South Asian restaurants in Birmingham”, International Journal of Urban and Regional Research, 26 (1): 24-40.

RATH, Jan, and Robert KLOOSTERMAN, 2000, "A critical review of research on immigrant entrepreneurship", International Migration Review, 34 (3): 1-15.

ROCHA-TRINDADE, Maria Beatriz, 2007, "Migrações: o fim dos paradigmas clássicos", Cidade Solidária, 10 (18): 6-11.

SEABrA, Teresa, 2010, Adaptação e Adversidade: O Desempenho Escolar dos Alunos de Origem Indiana e Cabo-Verdiana no Ensino Básico. Lisbon, Imprensa de Ciências Sociais.

TROVÃO, Susana, 2012, "Comparing post-colonial identity formations: legacies of Portuguese and British colonialisms in East Africa”, Social Identities, 18 (3): 261-280.

WALDINGER, Roger, D. Mc. EVOY, and H. ALDRICH, 1990, "Spatial dimensions of opportunity structures", in R. Waldinger, D. Mc. Evoy and H. Aldrich (eds.), Ethnic Entrepreneurs: Immigrant Business in Industrial Societies. Newbury Park, CA, Sage, 106-130.

WERBNER, Pnina, 2001, "Metaphors of spatiality and networks in the plural city: a critique of the ethnic enclave economy debate", Sociology, 35 (3): 67 1-693.

ZUKIN, Sharon, 2009, "Destination culture: how globalization makes all cities look the same”, Inaugural Working Paper Series [Center for Urban and Global Studies at Trinity College], I (1): 1-26. 